\title{
Prostaglandin E2 stimulates COX-2 expression via mitogen-activated protein kinase p38 but not ERK in human follicular dendritic cell-like cells
}

Whajung Cho ${ }^{1}$ and Jongseon Choe ${ }^{2^{*}}$

\begin{abstract}
Background: Prostaglandin E2 ( $\left.\mathrm{PGE}_{2}\right)$ is an endogenous lipid mediator of inflammation. Its production is regulated by the rate-limiting upstream enzyme cyclooxygenase-2 (COX-2). We have recently demonstrated that the major cell type expressing COX-2 in the germinal center is follicular dendritic cell (FDC). In this study, to elucidate the molecular mechanism of $\mathrm{PGE}_{2}$ in COX-2 production, we asked whether mitogen-activated protein kinases ERK and p38 might regulate COX-2 expression.

Results: FDC-like cells were used to analyze the phosphorylation kinetics of ERK and p38 and the impact of genetic knockdown. PGE 2 stimulation gave rise to a rapid increase of p38 but not ERK phosphorylation. In contrast, IL-1 $1 \beta$ induced phosphorylation of both MAPKs. Knockdown of p38 resulted in a marked suppression of COX-2 expression induced by either $P G E_{2}$ or IL-1 $\beta$. ERK knockdown did not significantly affect the effect of $P G E_{2}$ and IL-1 $\beta$ on COX-2 induction. The differential results of p38 and ERK siRNA transfection were reproduced in the production of prostaglandins and in experiments performed with pharmacologic inhibitors.

Conclusions: Our data indicate that p38 is essentially required for $\mathrm{PGE}_{2}$ to induce COX-2 expression in FDC-like cells. The current study helps to expand our understanding of the biological function of FDC at the molecular level and provides a potential rationale for the pharmacologic or genetic approaches to regulate p38 MAPK in the treatment of various inflammatory disorders.
\end{abstract}

Keywords: Follicular dendritic cell, Prostaglandin, Cyclooxygenase, MAPK, p38

\section{Background}

Mitogen-activated protein kinases (MAPKs) are important intracellular signaling molecules responsible for the various cellular functions under normal or pathologic conditions. These serine/threonine-specific protein kinases transduce signals coming from a plethora of extracellular stimuli including cytokines and prostaglandins

\footnotetext{
*Correspondence: jchoe@kangwon.ac.kr

${ }^{2}$ BIT Medical Convergence Graduate Program and Department of Microbiology and Immunology, School of Medicine, Kangwon National University, Chuncheon, Gangwon 24341, Republic of Korea

Full list of author information is available at the end of the article
}

(PGs). There are three major families of MAPKs, ERK, p38, and JNK, and subfamilies in each type [1]. ERK and p38, in particular, appear to be critical molecules based on the results obtained from knockout (KO) animals. Mice with single $\mathrm{KO}$ of certain subfamily of either ERK or p38 undergo embryonic death. For example, Erk2 KO mice and $p 38 \alpha$ KO mice are embryonic lethal $[2,3]$ while the single $\mathrm{KO}$ of any Jnk gene does not lead to the embryonic lethality [4]. These earlier studies underscore the physiological importance of ERK and p38 MAPKs.

(c) The Author(s). 2020 Open Access This article is licensed under a Creative Commons Attribution 4.0 International License, which permits use, sharing, adaptation, distribution and reproduction in any medium or format, as long as you give appropriate credit to the original author(s) and the source, provide a link to the Creative Commons licence, and indicate if changes were made. The images or other third party material in this article are included in the article's Creative Commons licence, unless indicated otherwise in a credit line to the material. If material is not included in the article's Creative Commons licence and your intended use is not permitted by statutory regulation or exceeds the permitted use, you will need to obtain permission directly from the copyright holder. To view a copy of this licence, visit http://creativecommons.org/licenses/by/4.0/ The Creative Commons Public Domain Dedication waiver (http://creativecommons.org/publicdomain/zero/1.0/) applies to the data made available in this article, unless otherwise stated in a credit line to the data. 
Follicular dendritic cells (FDCs) are peculiar stromal cells observed in the B cell follicles of peripheral lymphoid organs [5]. Their cellular origin of mesenchymal stromal cells is a distinction of FDCs from other cellular components in the secondary lymphoid tissues most of which derive from hematopoietic stem cells [6]. The biological roles of FDC include $B$ cell recruitment to the follicles, presentation of native antigens on the surface, and provision of survival, proliferation, and differentiation signals to germinal center (GC) B cells [7-10]. In the course of efforts to understand the $\mathrm{GC}$ reactions at the molecular level, we have recently suggested another interacting pathway between FDC and B cells. We demonstrated the expression of cyclooxygenase-2 (COX-2) molecule in FDC-like cells in vitro and further verified FDCs as the major cell type expressing COX-2 in situ [11]. COX-2 is a well-known enzyme induced by various factors including inflammatory stimuli and serves the rate-determining role in the production of $\mathrm{PGE}_{2}$ [12]. Using the experimental system containing FDC-like cells, we showed that PGs promote the survival of GC B cells by preventing apoptosis [13], augment the antigenpresenting ability of B cells by increasing CD86 expression $[14,15]$, and exert a positive feedback effect on COX-2 expression [16]. These in vitro results and our previous results with $\mathrm{COX}-2 \mathrm{KO}$ mouse imply the important role of COX-2 molecule in the inflammation taking place in the immune tissues [17].

We have previously observed that ERK and p38 MAPKs are involved in COX-2 expression in FDC-like cells. For example, LPS-induced COX-2 expression was inhibited by ERK and p38 inhibitors, which was verified by the actual induction of phosphorylation of these MAPKs by LPS [18]. TGF- $\beta$-stimulated COX-2 induction also required ERK and p38 [19]. In the present study, we extended our previous reports and explored the intracellular pathway of $\mathrm{PGE}_{2}$-induced $\mathrm{COX}-2$ expression in FDC-like cells. $\mathrm{PGE}_{2}$ treatment resulted in a rapid increase of p38 but not ERK phosphorylation. In contrast, IL-1 $\beta$, whose effect was compared in parallel with $\mathrm{PGE}_{2}$, induced phosphorylation of both MAPKs. Knockdown of these MAPKs revealed that p38 is essential for $\mathrm{PGE}_{2}$ to induce COX-2 expression in FDC-like cells, in line with the phosphorylation results. Our data provide a potential rationale for the pharmacologic or genetic approaches to regulate p38 MAPK in the treatment of various inflammatory disorders.

\section{Results}

We have recently demonstrated that $\mathrm{PGE}_{2}$ stimulates COX-2 expression in human FDC-like cells via EP2 and EP4 surface receptors on the cell surface $[16,20]$. In this study, we further investigated the underlying intracellular mechanism by examining the potential role of ERK and p38 MAPKs in this process. Our earlier results suggest that both ERK and p38 molecules are involved in the signaling pathway to COX-2 expression [19]. First, the effects of $\mathrm{PGE}_{2}$ on the phosphorylation degrees of ERK and p38 proteins were analyzed by immunoblotting. The signaling molecule would display increased levels of phosphorylation since ERK and p38 are phosphorylated by MAP kinase/ERK kinase (MEK) to act on the target molecules [21]. $\mathrm{PGE}_{2}$ did not increase phosphorylated forms of ERK but rather reduced ERK phosphorylation at 60 and $120 \mathrm{~min}$ post-stimulation by approximately $50 \%$ compared to the control maintained without $\mathrm{PGE}_{2}$ (Fig. 1a). In contrast, p38 phosphorylation increase was evident from $15 \mathrm{~min}$ and continued until $60 \mathrm{~min}$. For instance, more than 2 -fold increase of p38 phosphorylation was observed at $30 \mathrm{~min}$ compared to the vehicle control. The elevated levels of p38 phosphorylation returned to background levels at $120 \mathrm{~min}$. The enhancing effect on p38 phosphorylation was triggered by $\mathrm{PGE}_{2}$ because such an activation was not observed in control cultures carried out collaterally in the absence of $\mathrm{PGE}_{2}$ (Fig. 1b). To explore whether the differential phosphorylation induction is specific to $\mathrm{PGE}_{2}$, we performed the phosphorylation kinetics of ERK and p38 after stimulation with IL-1 $\beta$. IL- $1 \beta$ is a strong inducer of COX-2 in

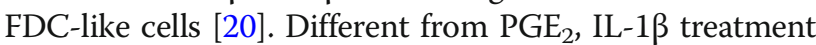
resulted in increased phosphorylation of both ERK and p38. For example, phosphorylation levels of both proteins were approximately 6 -fold higher at $15 \mathrm{~min}$ after IL-1 $\beta$ stimulation (Fig. 2). Both $\mathrm{PGE}_{2}$ and IL-1 $\beta$ did not significantly modulate the total protein levels of ERK and p38 molecules. Taken together, these results imply that ERK and p38 molecules are differentially involved in the COX-

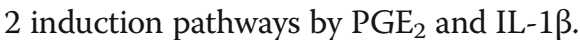

To determine the role of ERK and p38 in $\mathrm{PGE}_{2-}$ and IL-1 $\beta$-triggered COX-2 expression, the impact of ERK and p38 protein knockdown was analyzed. As shown in Fig. 3a, $\mathrm{PGE}_{2}$-induced COX-2 expression was significantly inhibited by p38 knockdown. About $65 \%$ reduced COX-2 protein was obtained in the cells transfected with p38 siRNA. Administration of FDC-like cells with siRNA against ERK did not significantly modulate the COX-2 induction. Similar results were obtained in experiments performed with pharmacologic inhibitors of ERK and p38 (Fig. 3b). PGE $_{2}$-induced COX-2 expression was significantly inhibited by SB203580 but not by PD098059. SB203580 is an inhibitor of p38 and PD098059 is a specific inhibitor of MEK-1, an upstream kinase of ERK. These inhibitors did not affect the expression of COX-1. COX-2 induction by other PGs, beraprost and $\mathrm{PGF}_{2 \alpha}$, was affected similarly by p38 knockdown (data not shown). Next, we conducted the siRNA transfection experiment to investigate the effects of ERK and p38 protein knockdown in IL-1 $\beta$-induced COX-2 expression. As 


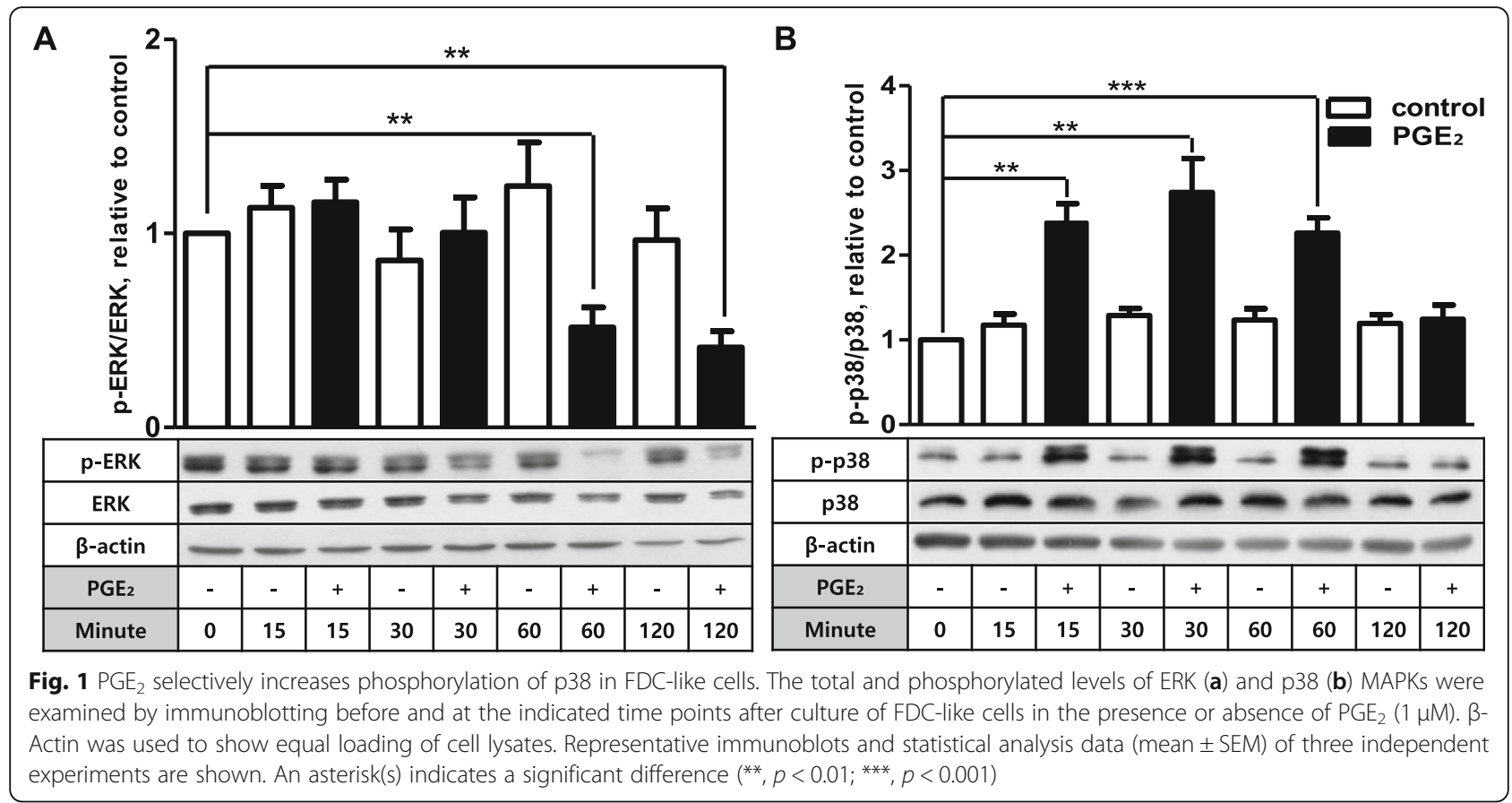

presented in Fig. 4, IL-1 $\beta$-induced COX-2 expression was suppressed approximately $50 \%$ by p 38 knockdown and almost completely by SB203580. ERK knockdown or PD098059 treatment did not affect the COX-2 induction stimulated by IL-1 $\beta$. The modulation of COX-2 protein expression either by IL-1 $\beta$ stimulation or p38 siRNA inhibition was reflected in the actual production of prostaglandins (Fig. 4b).

\section{Discussion}

Using primary human FDC-like cells, we demonstrate here the essential requirement for p38 MAPK in COX-2
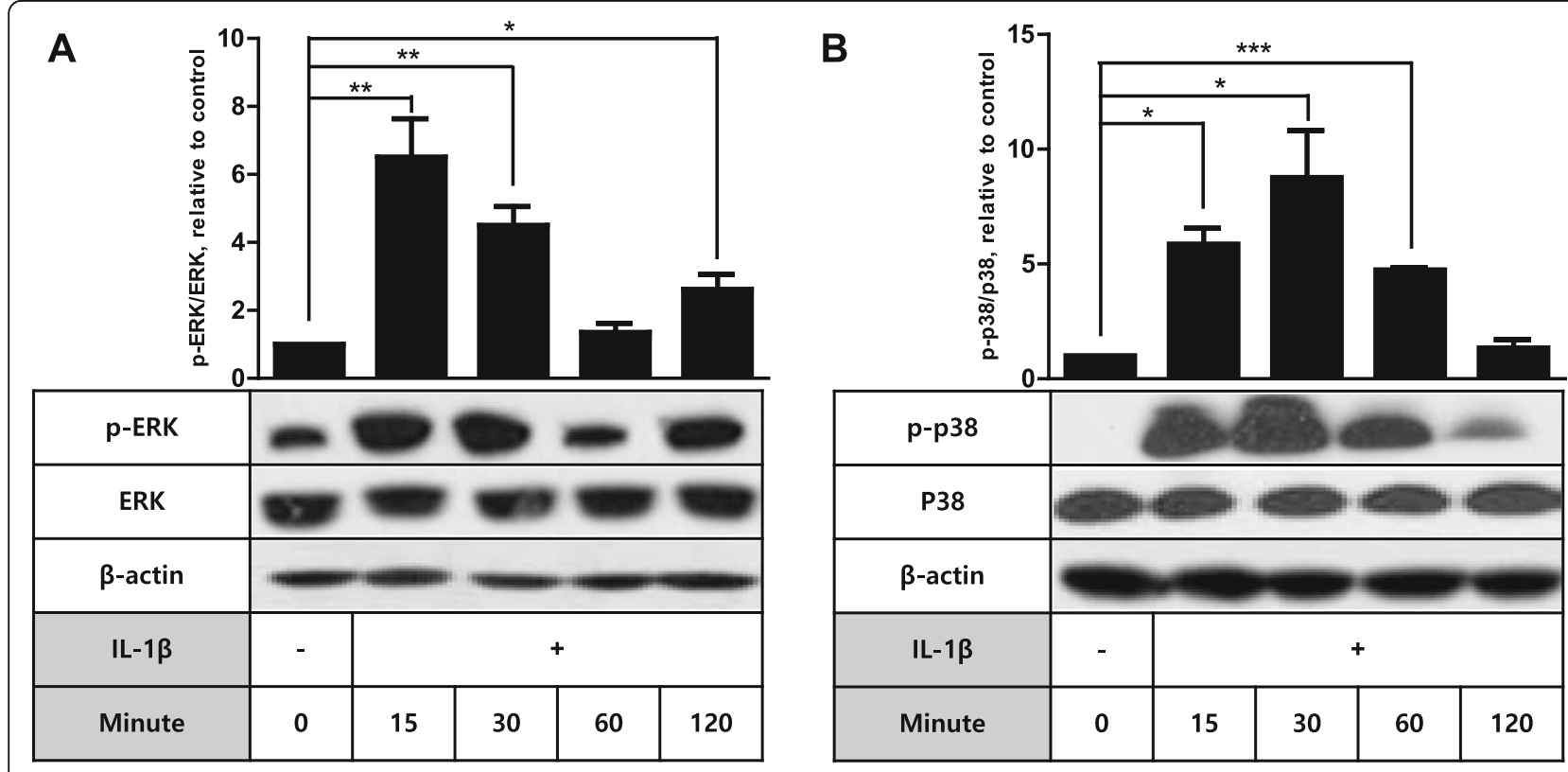

Fig. $2 \mathrm{LL}-1 \beta$ induces phosphorylation of both ERK and p38 in FDC-like cells. The total and phosphorylated levels of ERK (a) and p38 (b) MAPKs were examined by immunoblotting before and at the indicated time points after culture of FDC-like cells in the presence of $\mathrm{LL}-1 \beta(10 \mathrm{pg} / \mathrm{ml})$. Representative immunoblots and statistical analysis data (mean \pm SEM) of three (a) or two (b) independent experiments are depicted. An asterisk(s) indicates a significant difference $\left({ }^{*}, p<0.05 ;{ }^{* *}, p<0.01 ; * *, p<0.001\right)$ 


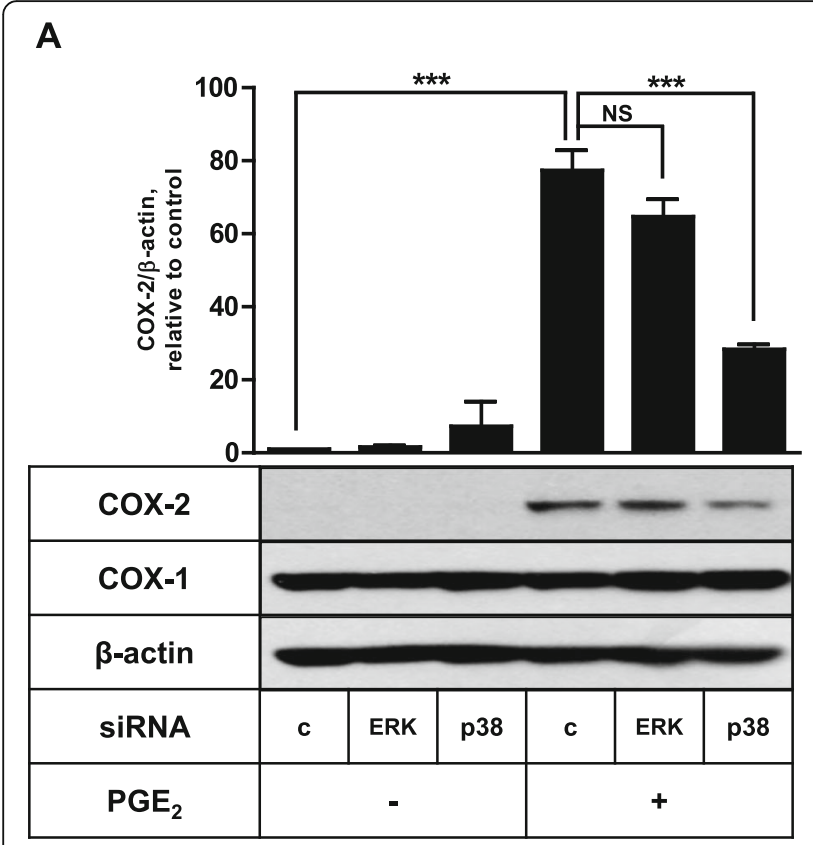

B

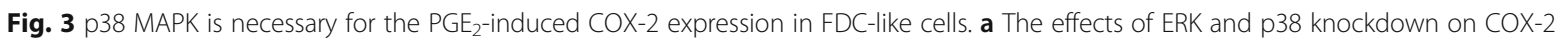
induction by $\mathrm{PGE}_{2}$ were examined with FDC-like cells that had been transfected with control or siRNA against ERK or p38 before the addition of $\mathrm{PGE}_{2}(1 \mu \mathrm{M})$. $\mathbf{b}$ The effects of PD098059 (PD, $\left.50 \mu \mathrm{M}\right)$ and SB203580 (SB, $\left.10 \mu \mathrm{M}\right)$ on COX-2 induction by PGE $\mathrm{F}_{2}$ were examined. FDC-like cells $\left(1 \times 10^{5}\right.$ cells) were cultured in the presence of PD098059 or SB203580 for $30 \mathrm{~min}$ and then added with $\mathrm{PGE}_{2}(1 \mu \mathrm{M})$ for $8 \mathrm{~h}$. The expression levels of COX$1, C O X-2$, and $\beta$-actin were measured by immunoblotting. Representative immunoblots and statistical analysis data (mean \pm SEM) of three independent experiments are shown. An asterisk(s) indicates a significant difference ( ${ }^{*}, p<0.05 ;{ }^{* *}, p<0.01 ;{ }^{* *}, p<0.001$; NS, non-significant). $\checkmark$, vehicle
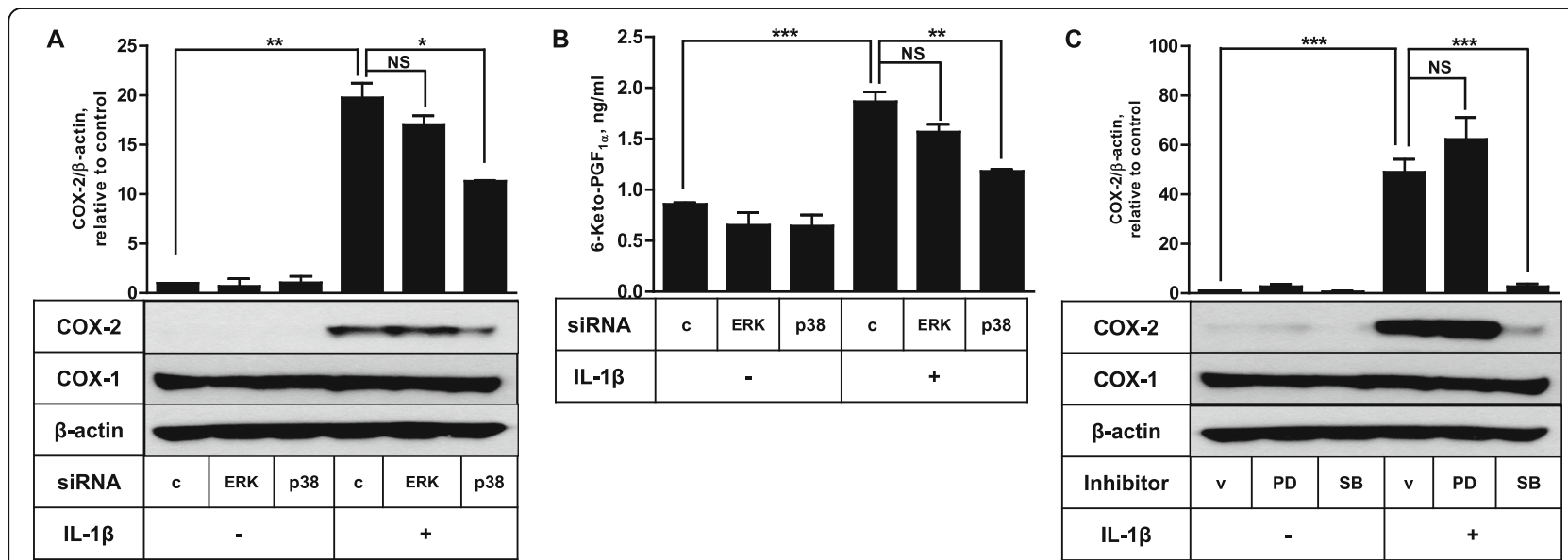

Fig. $4 \mathrm{IL}-1 \beta$-stimulated COX-2 expression in FDC-like cells depends on p38 MAPK. a The effects of ERK and p38 knockdown on COX-2 induction by IL-1 $\beta$ were examined with FDC-like cells that had been transfected with control or siRNA against ERK or p38 before the addition of IL-1 $\beta$ (10 $\mathrm{pg} / \mathrm{ml})$. The expression levels of COX-1, COX-2, and $\beta$-actin were measured by immunoblotting. $\mathbf{b}$ The amounts of 6-keto-PGF ${ }_{1 \mathbf{a}}$ in culture supernatants of (A) experiments were measured by EIA as described in Methods. c The effects of PD098059 (PD, $50 \mu M)$ and SB203580 (SB, $10 \mu M)$ on COX-2 induction by IL-1 $\beta$ were examined. Representative immunoblots and statistical analysis data (mean \pm SEM) of three independent experiments are shown. An asterisk(s) indicates a significant difference $\left({ }^{*}, p<0.05 ;{ }^{*}, p<0.01 ;{ }^{* *}, p<0.001\right.$; NS, non-significant). $v$, vehicle 
protein expression instigated by $\mathrm{PGE}_{2}$. $\mathrm{PGE}_{2}$ selectively induced phosphorylation of p38, and p38 knockdown gave rise to a marked suppression of $\mathrm{PGE}_{2}$-induced COX-2 expression. The current data suggest another intracellular mechanism on the positive effect of $\mathrm{PGE}_{2}$ on COX-2 expression. We have previously reported that $\mathrm{PGE}_{2}$ promotes COX-2 expression in FDC-like cells by inhibiting Akt phosphorylation [16]. Therefore, $\mathrm{PGE}_{2}$ that might be produced by autocrine or paracrine fashion in the GC appears to bind to EP2 or EP4 receptors on the surface of FDC [20] and enhances COX-2 expression by activating p38 MAPK and by suppressing Akt activity simultaneously. The upregulation of p38 phosphorylation and downregulation of Akt phosphorylation occurred with comparable kinetics in FDC-like cells. The elevated COX-2 expression and resultant PG production may contribute to the $\mathrm{GC}$ reactions in part by promoting the survival and antigen-presenting capability of $\mathrm{B}$ cells [13-15]. Figure 5 shows our working model for COX-2 induction mechanisms in FDC that is based upon our experimental results presented here and previously.

p38 MAPK was required while ERK was dispensable for COX-2 induction in FDC-like cells. Compared with siRNA knockdown that did not deplete all the p38 proteins in target cells, almost complete inhibition of COX-
2 was obtained with p38 inhibitor treatment, implying the essential requirement of p38 MAPK. Similar to this result, many investigators report that p38 MAPK plays the essential role in the IL- $1 \beta$-stimulated COX-2 expression in human lung fibroblasts and MDA-MB-231 breast cancer cells [22, 23]. However, unlike FDC-like cells, not only p38 but also ERK mediates COX-2 induction by IL$1 \beta$ in human colorectal cancer cells [24]. In a sharp contrast, IL-1 $\beta$-treated COX-2 induction in human endometrial stromal cells was inhibited by ERK but not p38 inhibitors [25]. These data imply that COX-2 expression is regulated by distinct MAPKs in different cell types. In our hands, MDA-MB-231 breast epithelial cells did not respond to IL-1 $\beta$, and COX-2 expression was not modulated as reported elsewhere [26].

Both $\mathrm{PGE}_{2}$ and IL- $1 \beta$ displayed the common feature of p38 activation and p38 requirement for COX-2 induction. This result may be regarded as a molecular mechanism for our recent observation of a synergistic effect of $\mathrm{PGE}_{2}$ and $\mathrm{IL}-1 \beta$ in COX-2 induction [20], implying that the synergy of $\mathrm{PGE}_{2}$ and $\mathrm{IL}-1 \beta$ may be achieved partly by synergistic augmentation of p38 activity. Inasmuch as FDC is localized in the microenvironment of GC, the synergy suggests that $\mathrm{PGE}_{2}$ takes part in the early stage of inflammatory response by providing more

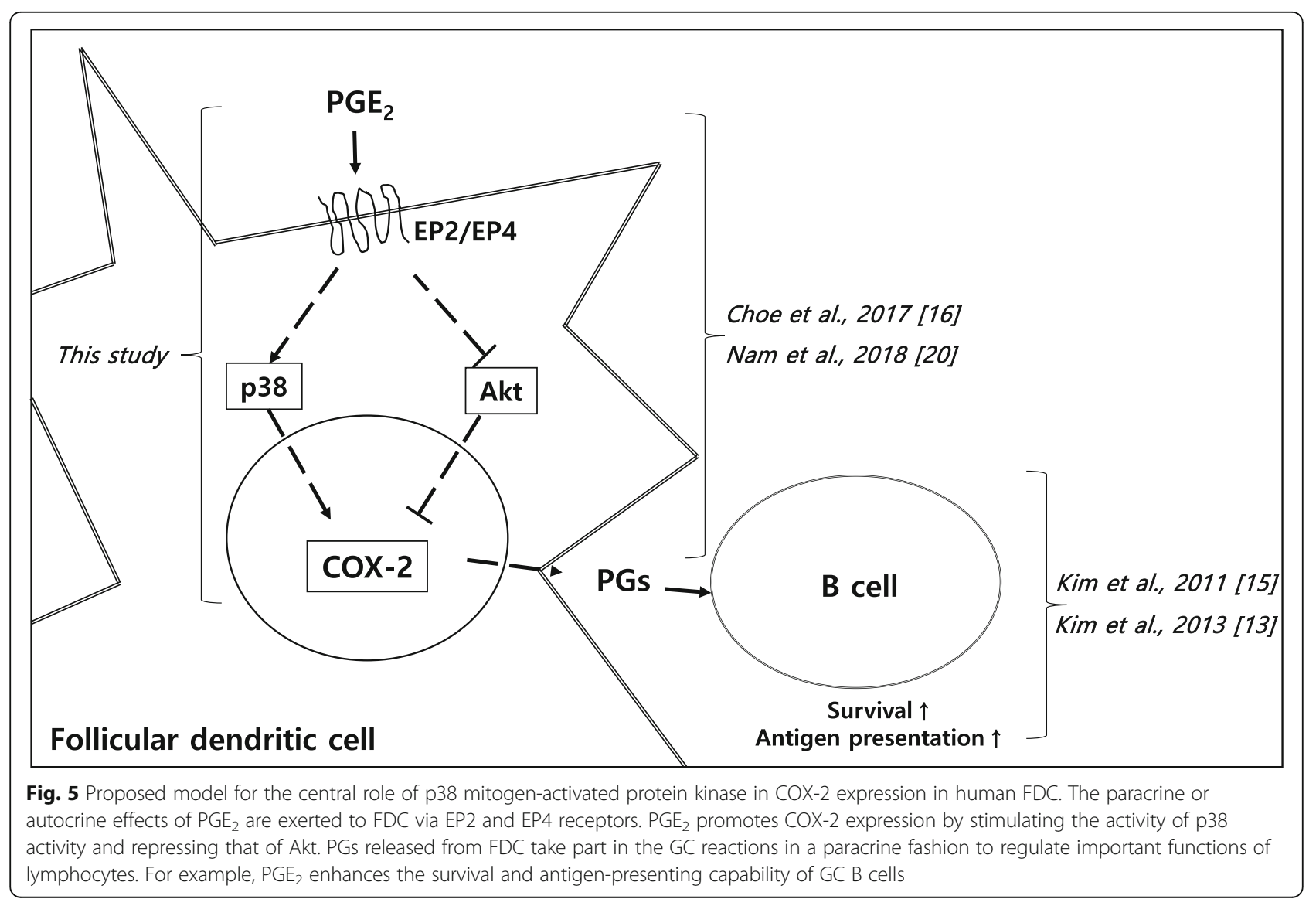


PGs to the ongoing responses initially triggered by proinflammatory cytokines such as IL-1 $\beta$. IL- $1 \beta$ is produced at the initial stage of inflammation [27]. This speculation for the inflammation-amplifying role for $\mathrm{PGE}_{2}$ is supported by several reports from other research groups. In response to endogenous $\mathrm{PGE}_{2}$, pro-inflammmatory cytokines are released from monocytes and synovial fibroblasts $[28,29]$.

Although the physiological relevance of the current data is unclear, the results are in line with the general concept that MAPK p38 is involved in inflammation while ERK plays pivotal roles in cellular proliferation [30]. $\mathrm{PGE}_{2}$ did not modulate the proliferation of FDClike cells in the range of $0.01 \sim 10 \mu \mathrm{M}$ concentrations (Supplementary Fig. 1). In this context, the increased ERK phosphorylation after IL-1 $\beta$ treatment is enigmatic since this cytokine does not significantly affect the growth of FDC-like cells. The target molecules and biological function of IL-1ß-induced phosphorylated ERK remain to be investigated.

\section{Conclusions}

In conclusion, we demonstrate in this study the requirement of p38 MAPK in $\mathrm{PGE}_{2}$-stimulated COX-2 protein in FDC-like cells. Considering the pivotal role of $\mathrm{PGE}_{2}$ in the inflammatory microenvironment, p38 MAPK regulation via pharmacologic or genetic approaches may be taken in the treatment of various inflammatory disorders.

\section{Methods}

\section{Antibodies and other reagents}

Antibodies against ERK, phosphorylated ERK, p38, phosphorylated p38 MAPKs were purchased from Santa Cruz Biotechnology, Inc. Specific antibodies to COX-1 and COX-2 were purchased from Cell Signaling Technology. Anti- $\beta$-actin antibody was obtained from Sigma-Aldrich. Secondary antibodies were horseradish peroxidase (HRP)conjugated anti-mouse IgG (Southern Biotech) and antirabbit IgG (Koma Biotech). $\mathrm{PGE}_{2}$ was purchased from Cayman Chemical, and IL-1 $\beta$ from R\&D Systems. All the siRNA duplexes were obtained from Ambion Inc. as described previously [19]. PD098059 and SB203580 were purchased from A.G. Scientific, Inc.

\section{Cell culture}

FDC-like cells are primary cultured cells. They are fibroblastic adherent cells obtained through the enzyme digestion of human tonsils as described previously [31]. The purity of cells was more than $98 \%$ when assessed by a FACSCalibur (BD Biosciences) for the expression of FDC-specific marker $3 \mathrm{C} 8$ as shown previously in the supplementary figure of representative phenotypic analysis data [32]. They proliferate under the conventional culture condition and display antigenic and functional features of FDC [33]. FDC-like cells are used until they exhibit degenerate features in culture. Cell culture media was RPMI-1640 media (GIBCO) containing 10\% fetal bovine serum (Hyclone), $2 \mathrm{mML}$-glutamine, $100 \mathrm{U} / \mathrm{ml}$ penicillin G (Sigma-Aldrich), and $100 \mu \mathrm{g} / \mathrm{ml}$ streptomycin (Life Technologies).

\section{Immunoblotting}

Cultured FDC-like cells were lysed in a buffer containing $50 \mathrm{mM}$ Tris- $\mathrm{HCl}$ (pH 7.5), $150 \mathrm{mM} \mathrm{NaCl}, 0.5 \%$ Nonidet P-40, $1 \mathrm{mM}$ dithiothreitol, $5 \mathrm{mM}$ EDTA, and protease inhibitor mixture at $4{ }^{\circ} \mathrm{C}$. For clarification, cell lysates were centrifuged at $12,000 \mathrm{rpm} / \mathrm{min}$ at $4{ }^{\circ} \mathrm{C}$ for $10 \mathrm{~min}$. The supernatants were harvested, and then total protein concentrations were measured using Bio-Rad protein assay reagent. Cellular proteins were heated at $95^{\circ} \mathrm{C}$ for $3 \mathrm{~min}$ and then separated by SDS-PAGE, followed by electrotransfer to polyvinylidene difluoride (PVDF) membranes. PVDF membrane was then blocked for $1 \mathrm{~h}$ with Tris-buffered saline containing $0.05 \%(\mathrm{v} / \mathrm{v})$ Tween 20 and $5 \%(\mathrm{w} / \mathrm{v})$ non-fat dry milk. The membranes were incubated with appropriate antibodies and then with SuperSignal West Pico Chemiluminescent Substrate (Pierce) and exposed to X-ray films.

\section{siRNA transfection}

FDC-like cells were cultured to $50 \sim 60 \%$ confluence in $100 \mathrm{~mm}$ plates. For each plate, $40 \mathrm{nM}$ of each siRNA and $24 \mu \mathrm{l}$ lipofectamine (Invitrogen) were separately diluted in $400 \mu \mathrm{l}$ serum-free medium without antibiotics and then mixed together. The mixture was incubated at RT for $45 \mathrm{~min}$. The plates containing FDC-like cells were washed with serum-free medium, added with $5 \mathrm{ml}$ serum-free medium, and then with the mixture. The plates were incubated at $37^{\circ} \mathrm{C}$ for $8 \mathrm{~h}$, followed by the addition of a growth medium containing 10\% serum. Cells were used for the experiments after $48 \mathrm{~h}$ of additional incubation. The degree of gene-silencing was verified by immunoblotting.

\section{Enzyme immunoassay (EIA) to measure PGs}

The amounts of $\mathrm{PGI}_{2}$ (6-keto-PGF ${ }_{1 \alpha}$ ) in the culture supernatants of FDC-like cells were measured using EIA kits conforming to the manufacturer's instructions (Cayman Chemical).

\section{Statistical analysis}

Statistical analyses of data were carried out using GraphPad Prism 5.04 software to be presented as the mean \pm SEM of three independent experiments. The statistical significance of differences was determined using Student's $t$ test. $P<0.05$ was considered significant. 


\section{Supplementary information}

Supplementary information accompanies this paper at https://doi.org/10. 1186/s12865-020-00347-y.

Additional file 1: Supplementary Figure 1. $P G E_{2}$ does not modulate the proliferation of FDC-like cells. The effect of $\mathrm{PGE}_{2}$ on cell growth was examined by culturing FDC-like cells in the presence or absence of indicated concentrations of PGE for $72 \mathrm{~h}$. Indomethacin (Indo) was used at $100 \mu \mathrm{M}$ after determining its inhibitory concentration. The impact on cell proliferation was measured by Cell counting kit-8 (Dojindo Molecular Technologies) according to the manufacturer's instructions. Representative results and statistical analysis data (mean \pm SEM) are shown. An asterisk indicates a significant difference $\left.{ }^{*}, p<0.05\right)$.

\section{Abbreviations}

COX: Cyclooxygenase; FDC: Follicular dendritic cell; GC: Germinal center; MAPK: Mitogen-activated protein kinase; MEK: MAP kinase/ERK kinase; NO: Knockout; PG: Prostaglandin

\section{Acknowledgements}

Not applicable.

\section{Authors' contribution}

JC designed this study. WC and JC contributed to the collection, analysis and interpretation of data. JC wrote the manuscript. All authors read and approved the final manuscript.

\section{Funding}

This work was supported by the National Research Foundation (NRF) grant funded by the Ministry of Science and ICT of Korea (2019R1A2C1004696) and also by 2018 research grant from Kangwon National University (No. 520180095). Funding bodies have no role in design of the study and collection, analysis, interpretation of data or in writing the manuscript.

\section{Availability of data and materials}

The dataset of the current study is available from the corresponding author at a reasonable request.

\section{Ethics approval and consent to participate}

This study used patient tonsil samples collected after written informed consent from patients, and used in accordance with ethics approval from the Ethics Committee of Kangwon National University (The protocol number is 2016-10-002-001).

\section{Consent for publication}

Not applicable.

\section{Competing interests}

The authors declare that they have no competing interests.

\section{Author details}

${ }^{1}$ Research Center, Scripps Korea Antibody Institute, Chuncheon, Gangwon 24341, Republic of Korea. ${ }^{2}$ BIT Medical Convergence Graduate Program and Department of Microbiology and Immunology, School of Medicine, Kangwon National University, Chuncheon, Gangwon 24341, Republic of Korea.

Received: 15 January 2020 Accepted: 24 March 2020

Published online: 17 April 2020

\section{References}

1. Morrison DK. MAP kinase pathways. Cold Spring Harb Perspect Biol. 2012;4 a011254.

2. Hatano N, Mori Y, Oh-hora M, Kosugi A, Fujikawa T, Nakai N, Niwa H, Miyazaki J-I, Hamaoka T, Ogata M. Essential role for ERK2 mitogen-activated protein kinase in placental development. Genes Cells. 2003:8(11):847-56.

3. Mudgett JS, Ding J, Guh-Siesel L, Chartrain NA, Yang L, Gopal S, Shen MM. Essential role for p38a mitogen-activated protein kinase in placental angiogenesis. Proc Natl Acad Sci U S A. 2000;97(19):10454-9.
4. Yamasaki T, Kawasaki H, Nishina H. Diverse roles of JNK and MKK pathways in the brain. J Signal Transduct. 2012;2012:459265.

5. MacLennan ICM. Germinal centers. Annu Rev Immunol. 1994;12:117-39.

6. El Shikh MEM, Pitzalis C. Follicular dendritic cells in health and disease. Front Immunol. 2012;3:292.

7. Gunn MD, Ngo VN, Ansel KM, Ekland EH, Cyster JG, Williams LT. A B-cellhoming chemokine made in lymphoid follicles activates Burkitt's lymphoma receptor-1. Nature. 1998:391(6669):799-803.

8. Mackay F, Schneider P, Rennert P, Browning J. BAFF AND APRIL: a tutorial on B cell survival. Annu Rev Immunol. 2003:21:231-64.

9. Zhang X, Park C-S, Yoon S-O, Li L, Hsu Y-M, Ambrose C, Choi YS. BAFF supports human $B$ cell differentiation in the lymphoid follicles through distinct receptors. Int Immunol. 2005;17(6):779-88.

10. Allen CD, Okada T, Tang HL, Cyster JC. Imaging of germinal center selection events during affinity maturation. Science. 2007;315(5811):528-31.

11. Kim J, Lee S, Jeoung D, Kim Y-M, Choe J. Activated human B cells stimulate COX-2 expression in follicular dendritic cell-like cells via TNF-a. Mol Immunol. 2018;94(1):1-6

12. Takai E, Tsukimoto M, Kojima S. TGF- $\beta 1$ downregulates COX-2 expression leading to decrease of PGE2 production in human lung cancer A549 cells, which is involved in fibrotic response to TGF-B1. PLoS One. 2013;8(10):e76346.

13. Kim J, Lee S, Kim Y-M, Jeoung D-I, Choe J. Human follicular dendritic cells promote germinal center B cell survival by providing prostaglandins. Mol Immunol. 2013;55(3-4):418-23

14. Kim J, Kim Y-M, Jeoung D, Choe J. Human follicular dendritic cells promote the APC capability of B cells by enhancing CD86 expression levels. Cell Immunol. 2012;273(2):109-14.

15. Kim J, Park C-S, Park C-H, Jeoung D-I, Kim Y-M, Choe J. Beraprost enhances the APC function of B cells by upregulating CD86 expression levels. J Immunol. 2011;186(7):3866-73.

16. Choe J, Yoon Y, Kim J, Jung Y-J. Positive feedback effect of PGE2 on cyclooxygenase-2 expression is mediated by inhibition of Akt phosphorylation in human follicular dendritic cell-like cells. Mol Immunol. 2017;87(1):60-6.

17. Lee E, Kim J, Kim Y-M, Ha KS, Jeoung D-I, Sin J-I, Choe J. Beraprost enhances production of antigen-specific lgG isotypes without modulating germinal center B cell generation and the affinity maturation. Int Immunopharmacol. 2013:15(4):735-42

18. Cho W, Kim Y, Jeoung D, Kim Y-M, Choe J. IL-4 and IL-13 suppress prostaglandins production in human follicular dendritic cells by repressing COX-2 and mPGES-1 expression through JAK1 and STAT6. Mol Immunol. 2011;48(6-7):66-972.

19. Cho W, Kim Y, Kim J, Park S, Park D, Kim B-C, Jeoung D, Kim Y-M, Choe J. Suppressor of cytokine signaling 1 is a positive regulator of TGF- $\beta$-induced prostaglandin production in human follicular dendritic cell-like cells. Immunol. 2015;194(9):4287-97.

20. Nam J, Kwon B, Yoon Y, Choe J. PGE2 stimulates COX-2 expression via EP2/4 receptors and acts in synergy with $\mathrm{IL}-1 \beta$ in human follicular dendritic celllike cells. Eur J Inflamm. 2018;16(1):1-9.

21. Wilsbacher JL, Goldsmith EJ, Cobb MH. Phosphorylation of MAP kinases by MAP/ERK involves multiple regions of MAP kinases. J Biol Chem. 1999; 274(24):16988-94

22. Ridley SH, Sarsfield SJ, Lee JC, Bigg HF, Cawston TE, Taylor DJ, DeWitt DL, Saklatvala J. Actions of IL-1 are selectively controlled by p38 mitogen-activated protein kinase: regulation of prostaglandin $\mathrm{H}$ synthase-2, metalloproteinases, and IL-6 at different levels. J Immunol. 1997;158(7):3165-73.

23. Park EJ, Kwon TK. Rottlerin enhances IL-1ß-induced COX-2 expression through sustained p38 MAPK activation in MDA-MB-231 human breast cancer cells. Exp Mol Med. 2011:43(12):669-75.

24. Liu W, Reinmuth N, Stoeltzing O, Parikh AA, Tellez C, Williams S, Jung YD, Fan F, Takeda A, Akagi M, et al. Cyclooxygenase- 2 is up-regulated by interleukin-1 $\beta$ in human colorectal cancer cells via multiple signaling pathways. Cancer Res. 2003;63(13):3632-6.

25. Tamura M, Sebastian S, Yang S, Gurates B, Fang Z, Bulun SE. Interleukin-1ß elevates cyclooxygenase-2 protein level and enzyme activity via increasing its mRNA stability in human endometrial stromal cells: an effect mediated by extracellularly regulated kinases 1 and 2. J Clin Endocrinol Metab. 2002; 87(7):3263-73.

26. Schrey MP, Patel KV. Prostaglandin $E_{2}$ production and metabolism in human breast cancer cells and breast fibroblasts. Regulation by inflammatory mediators. Br J Cancer. 1995;72(6):1412-9. 
27. Keyel PA. How is inflammation initiated? Individual influences of IL-1, IL-18 and HMGB1. Cytokine. 2014;69(1):136-45.

28. Inoue $H$, Takamori M, Shimoyama Y, Ishibashi H, Yamamoto S, Koshihara Y. Regulation by $\mathrm{PGE}_{2}$ of the production of interleukin-6, macrophage colony stimulating factor, and vascular endothelial growth factor in human synovial fibroblasts. Br J Pharmacol. 2002;136(2):287-95.

29. Zaslona Z, Påalsson-McDermott EM, Menon D, Haneklaus M, Flis E, Prendeville H, Corcoran SE, Peters-Golden M, O'Neill LAJ. The induction of pro-IL-1 $\beta$ by lipopolysaccharide requires endogenous prostaglandin $E_{2}$ production. J Immunol. 2017;198(9):3558-64.

30. Kim EK, Choi E-J. Pathological roles of MAPK signaling pathways in human diseases. Biochim Biophys Acta. 2010;1802(4):396-405.

31. Kim H-S, Zhang X, Choi YS. Activation and proliferation of follicular dendritic cell-like cells by activated T lymphocytes. J Immunol. 1994;153(7):2951-61.

32. Kim J, Kim DW, Chang W, Choe J, Kim J, Park C-S, Song K, Lee I. Wnt5a is secreted by follicular dendritic cells to protect germinal center B cells via Wnt/Ca ${ }^{2+} /$ NFAT/NF-KB-B cell lymphoma 6 signaling. J Immunol. 2012;188(1): 182-9.

33. Lee IY, Choe J. Human follicular dendritic cells and fibroblasts share the $3 \mathrm{C} 8$ antigen. Biochem Biophys Res Commun. 2003;304(4):701-7.

\section{Publisher's Note}

Springer Nature remains neutral with regard to jurisdictional claims in published maps and institutional affiliations.

Ready to submit your research? Choose BMC and benefit from:

- fast, convenient online submission

- thorough peer review by experienced researchers in your field

- rapid publication on acceptance

- support for research data, including large and complex data types

- gold Open Access which fosters wider collaboration and increased citations

- maximum visibility for your research: over $100 \mathrm{M}$ website views per year

At BMC, research is always in progress.

Learn more biomedcentral.com/submissions 